\title{
Print and the Reformation: A Drama in Three Acts
}

\author{
Andrew Pettegree
}

Throughout the history of printing, questions of design have been crucial to the development of the book industry. This is especially the case with the development of the title page, the most crucial design feature for which there was no obvious model inherited from the manuscript book world. The Reformation both revolutionized the market for books and stimulated crucial innovations in the design and selling of books. This began in Wittenberg, where the partnership of Martin Luther and Lucas Cranach played a critical role in shaping the Reformation pamphlet. In lands more hostile to the Reformation, the design task was more complex, since design features intended to facilitate identification could place the seller or owner in deadly danger. This essay concludes with an examination of the market for devotional literature in the Dutch Republic, the home to Europe's most buoyant center of book production.

I $\mathrm{N}$ this five-hundredth anniversary of the Reformation, much will be said of print and Protestantism. Luther's movement was founded on a printed document, the Ninety-Five Theses, and spread abroad by a torrent of print. So in this of all years, it seems almost perverse to remark that the natural affinity between print and Protestantism is something far more often assumed than demonstrated. The tradition, of course, has deep roots, going back to the Reformation itself. Luther, albeit retrospectively, celebrated print as God's highest act of grace. In this he echoed the earliest boosters of the new invention, who spoke of print as a natural instrument of enlightenment, a civilizing force: a rhetorical trope that still lives on in the influential work of Elizabeth Eisenstein and her print revolution. ${ }^{1}$

It might seem churlish to remark that the first enthusiasts for print had a far better idea of what they wanted out of print - that is, more and cheaper books for themselves - than how the industry could be put on a viable economic footing. The humanist scholars who welcomed the new invention ultimately

\footnotetext{
${ }^{1}$ Elizabeth Eisenstein, The Printing Press as an Agent of Change: Communications and Cultural Transformations in Early Modern Europe (Cambridge: Cambridge University Press, 1979); and Eisenstein, The Printing Revolution in Early Modern Europe (Cambridge: Cambridge University Press, 1983). For the earliest enthusiasts for print, see now especially Eisenstein, Divine Art, Infernal Machine: The Reception of Printing in the West from First Impressions to the Sense of an Ending (Philadelphia: University of Pennsylvania, 2011).
}

Andrew Pettegree is Professor of Modern History at the University of St. Andrews. 
furnished too small a client base to absorb the many thousands of copies now flooding the market thanks to the multiplier effect of the new technology. For most early printers, the experimental age would end in bankruptcy. ${ }^{2}$ Somewhat ironically in view of subsequent events, it was the Catholic Church that in the first seventy years provided the most reliable underpinning of the new industry. Liturgical books, volumes of sermons, books of hours, and devotional texts gave the publishers the sort of steady work necessary to sustain a print shop. Of course nothing was more profitable for the printers than the varied panoply of texts that accompanied an indulgence campaign: the Papal Bull of authorization, the instructions to confessors, sermons, advertisements, and the thousands and thousands of printed certificates bestowed on those who had made a pious donation. ${ }^{3}$ While intellectuals like Erasmus might have misgivings about indulgences, printers had nothing with which to reproach the church - most, indeed, valued it as their most valuable client. ${ }^{4}$

So the synergy of print and Protestantism is not as obvious as it might appear: this was a relationship that had to be crafted. I want to explore how this was achieved in three parts, the three acts of my title. First, I will review how Luther built what was in effect a new audience for print, by leading new readers into the realms of theological controversy, in the process making an unlikely print capital out of a small outpost of the university world, Wittenberg. Luther's movement also fashioned a new livery for religious publishing; my second part considers how print could serve the movement in places where high visibility ceased to be an asset, and instead became a source of deadly danger. My final section turns to the seventeenth century and considers the relationship between print and Protestantism in Europe's most sophisticated and innovative book world, that of the Dutch Republic.

\section{Rebooting the Print Industry}

Before Luther came on the scene, print was, to a large extent, still a technology looking for a purpose. In the seventy years since Gutenberg had concluded his

\footnotetext{
${ }^{2}$ Andrew Pettegree, The Book in the Renaissance (New Haven, Conn.: Yale University Press, 2010).

${ }^{3}$ Falk Eisermann, Verzeichnis der typographischen Einblattdrucke des 15. Jahrhunderts im Heiligen Römischen Reich Deutscher Nation: VE 15 (Wiesbaden: Reichert, 2004); Eisermann, "The Indulgence as a Media Event: Developments in Communication Through Broadsides in the Fifteenth Century," in Promissory Notes on the Treasury of Merits: Indulgences in Late Medieval Europe, ed. R. W. Swanson (Leiden: Brill, 2006), 309-330; and Nikolaus Paulus, "Raimund Peraudi als Ablasskommissar," Historisches Jahrbuch 21 (1900): 645-682.

${ }^{4}$ W. E. Winterhager, "Ablasskritik als Indikator historischen Wandels vor 1517: ein Beitrag zu Voraussetzung und Einordnung der Reformation," Archiv für Reformationsgechichte 90 (1999): 6-71.
} 
successful experiments with moveable type, publishers had essentially mastered the technical aspects of printing. But in other respects, this was a remarkably conservative industry. Printers had either published the books urged on them by intellectuals or, mindful of consumer resistance to texts that differed too radically from the familiar manuscripts, they had relied on a diet of medieval bestsellers. This innate conservatism contrasted markedly with the radical innovative spirit that is meant to have characterized the new industry. With too many copies of the same narrow range of texts, unsold copies piled up, and printers ran out of money. The result was a necessary restructuring of the industry. Having spread its tentacles very rapidly through the European landmass, fuelled by curiosity and technological enthusiasm rather than any thought-through business plan, print gradually retreated to the major commercial cities, where publishers with access to investment capital could sustain the sort of investment required for big projects before spending could be recouped from sales. The publishers who survived were ever more dependent on institutional customers, the church and the state. Half of all the books published between 1450 and 1520 were full or partial editions of biblical texts, sermons, liturgical books, and devotional tracts. ${ }^{5}$ These were sometimes big books, whereas printed ordinances, or indeed indulgence certificates, represented the very best sort of commission: a simple broadsheet, printed on one side only, delivered, for cash, for a single client; no wonder the printers of Germany yearned for this sort of work. The controversial Saint Peter's Indulgence of 1515 was no exception, and among those who published batches of indulgences or associated texts were many of Germany's leading printers, including Melchior Lotter in Leipzig, Silvan Otmar in Augsburg, Adam Petri in Basel, and Friedrich Peypus in Nuremberg. ${ }^{6}$ Four years later, all of these men would be printing for Luther. Adam Petri, indeed, would be one of the first to print Luther's Ninety-Five Theses against indulgences.

Luther's movement offered Germany's printers what the new technology required for ultimate sustainability: access to new readers through a new sort of product - shorter, simpler books, cheaper to produce, in German rather than Latin, and selling to local audiences. This was the mirror image of the texts anticipated as the principle products of the press by the print industry's original humanist boosters.

The transformative impact of this second print revolution can be seen in the extraordinary history of publishing in Luther's own city, Wittenberg.

\footnotetext{
${ }^{5}$ Using the Universal Short Title Catalogue (http://www.ustc.ac.uk/) (hereafter cited as USTC), search "religious" and "bibles" during the year range 1450-1520.

${ }^{6} \mathrm{Hans}$ Volz, "Der St. Peters-Ablass und das Deutsche Druckgewerbe," Gutenberg-Jahrbuch (1966): 156-172.
} 
Wittenberg was the sort of place that should have had no real role in a rationally organized print industry. It was a small place, far away from the major centers of European commerce. Its students and professors could be furnished the books they required from nearby Leipzig and Erfurt. When the ambitious ruler, Frederick the Wise, was looking to build a library, he did what any Renaissance prince would do, and wrote to Aldus Manutius in Venice. ${ }^{7}$ Wittenberg was just the sort of place where print might have been established during the incunabula boom, and then just as quickly expired. In fact, there was no printing at all before 1502, and four printers would come and go before Johan Rhau-Grunenberg took over the shop in $1508 .{ }^{8}$ Like his predecessors, Rhau-Grunenberg occupied himself printing small literary works on commission from the local professors and the routine work of academic administration, such as dissertation theses. ${ }^{9}$ The quality of this work was rudimentary, based on a narrow range of typefaces, inexpertly deployed. University professors showed what they thought of it by having their more ambitious works sent off to Leipzig for publication. Even a publicity brochure, circulated to draw students to the university, was printed in Leipzig. ${ }^{10}$

All told, between 1502 and 1516, five successive printers published a total of 123 books, an average of eight a year. Now look at the Luther effect. Between 1517 and 1546, Wittenberg publishers turned out at least 2,721 works, an average of ninety per year. ${ }^{11}$ This represents around three million individual copies and includes many of the milestone works of the era, including multiple editions of Luther's German Bible. By 1525, there were five printers active in the town-some would establish printing houses that would be sustained for thirty years or more, a notable contrast with the instability of the first decade.

This vast blossoming of what was essentially a new industry was entirely due to Martin Luther. One in three of all the books published during these three decades were Luther's own works and another twenty percent were those of

\footnotetext{
${ }^{7}$ Maria Grossmann, Humanism in Wittenberg, 1485-1517 (Nieuwkoop: De Graaf, 1975), 100112 .

${ }^{8}$ Biographies in Christoph Reske, Die Buchdrucker des 16. und 17. Jahrhunderts im deutschen Sprachgebiet: auf der Grundlage des gleichnamigen Werkes von Josef Benzing (Wiesbaden: Harrassowitz, 2007).

${ }^{9}$ Andreas Gössner, "Die Anfänge des Buchdrucks für universitäre Zwecke am Beispiel Wittenbergs," in Bücher, Drucker, Bibliotheken in Mitteldeutschland, ed. Enno Bünz (Leipzig: Leipziger Universitätsverlag, 2006), 133-152.

${ }^{10}$ Andreas Meinhardi, Dialogus illustrate ac augustissime urbis albiorene vulgo vittenberg dicte situm amenitatem ac illustrationem docens tirocinia nobilium artiu iacentibus editus (Leipzig: Martin Lansberg, 1508).

${ }^{11}$ USTC; and Maria Grossmann, Wittenberger Drucke 1502-1517: Ein bibliographischer Beitrag zur Geschichte des Humanismus in Deutschland (Vienna: Krieg, 1971).
} 
his Wittenberg colleagues and followers. ${ }^{12}$ And the Luther effect proved enduring. Even after his death, the industry continued to grow, reaching 165 new editions in 1563 and over 200 annually in the last decade of the century. Wittenberg was now Germany's largest publishing center, eclipsing established centers of the book trade like Strasbourg and Cologne, overtaking even mighty Augsburg and Nuremberg. ${ }^{13}$ Thanks to its favorite son, Wittenberg had subverted the iron economics of publishing, the apparent requirement that major production centers could only be located in Europe's principal commercial cities.

Three major developments were necessary to achieve this transformation. The first was the extraordinary magnetic power of Luther's writing and his instinctive grasp of what publishers required of him. In the three years after the publication of the Ninety-Five Theses, Luther published sixty-five original works: most were short, about half less than eight pages long. ${ }^{14}$ Many were published in German. Characteristically, they would be published first in Wittenberg, then ricochet through Germany's major printing cities: Leipzig, Nuremberg, Augsburg, Basel, and Strasbourg, through locally published reprints. This, again, was a fundamentally new model of publishing. In the first age of print, dealing largely with expensive Latin books, it made far better sense for one publisher to publish a large edition and then distribute this throughout Europe. With pamphlets, it was far easier to send a single copy to a new location where the text could be reset, printed, and out on the streets in two days. By the time Luther came to the Diet of the German Empire at Worms in April 1521, an astonishing 615 editions of his works had been published. By year's end, he was not only the most published author of his day, but the most published ever in the history of print.

This barrage of print helped launch Luther as a public figure, and certainly thwarted the church authorities' hopes of having him quietly done away with, by far the preferred solution if the church hierarchy was to avoid terminal damage to the ongoing indulgence campaign. But most of the profits of selling Luther's texts accrued to shops outside Wittenberg. To the end of 1519, there was still only one printshop in Wittenberg, run by the stolid Johann Rhau-Grunenburg, a fervent supporter of Luther, but conservative in habits and maddeningly slow.

\footnotetext{
${ }^{12}$ USTC. See also, for a survey based on more rudimentary statistical data, Mark U. Edwards Jr., Printing, Propaganda, and Martin Luther (Berkeley: University of California, 1994).

${ }^{13}$ The figures are computed from the USTC.

${ }^{14}$ Josef Benzing and Helmut Claus, eds., Lutherbibliographie: Verzeichnis der gedruckten Schriften Martin Luthers bis zu dessen Tod, 2 vols. (Baden-Baden: Koerner, 1966-1994); and Bernd Moeller, "Das Berühmtwerden Luthers," Zeitschrift für Historische Forschung 15, no. 1 (1988): 65-92.
} 
Luther now took the matter in hand. In the summer of 1519, he had invited to Wittenberg the Leipzig printer Melchior Lotter. Lotter was an unlikely ally. Deeply embedded in the print industry, he had lately taken a leading role in the campaign against Luther. It had been Lotter who, in 1515, had published the manual for confessors for the indulgence campaign that had so offended Luther. $^{15}$ In 1518, he would publish the first Catholic attack on Luther, Tetzel's Rebuttal, and two editions of the Roman condemnation of Luther's teaching on indulgences. ${ }^{16}$ Yet even Lotter could see the profits to be made from printing Luther's works. In 1519, a deal was struck. Lotter would send his son, Melchior Jr., to Wittenberg along with a selection of his typefaces, far superior to those of Rhau-Grunenberg, and some new faces to be provisioned from Basel, the byword for typographical elegance north of the Alps. By the end of the year, the new press was up and running.

With the arrival of Lotter Jr., the look and the typographical proficiency of the Wittenberg editions of Luther's works improved immeasurably. The two shops working together were also better able to keep up with the incessant demand for new works, as Luther battled his opponents and set out his expanding agenda. But this was an unfinished revolution. Although Wittenberg books were now more proficiently produced, this was still, in Lotter's case, essentially the style of Leipzig. To create a specifically Wittenberg style, the movement had to make use of its most potent latent asset: the enormous workshop factory of Wittenberg's court printer, Lucas Cranach.

Cranach is best known to us as an artist - the man who created the great sequence of portraits of Luther. ${ }^{17}$ The two men were close, and firm allies in the work of the Reformation. What is less well-known is that Cranach was also a major player in the Wittenberg book industry. From 1521, he ran his

\footnotetext{
${ }^{15}$ Albrecht von Brandenburg, Archbishop of Mainz, Instructio summaria pro subcommissariis: penitentiariis cum confessoribus: in executionem gratie plenissimarum indulgentiarum: ac aliarum plenissimarum facultatum: in favorem basilice principis apostolorum de urbe: per sanctissimum dominum nostrum papam leonem decimum . . . (Leipzig: Melchior I Lotter, 1516), USTC 669147; and Volz, "St. Peters-Ablass."

${ }^{16}$ Martin Luther and Johann Jakob Tetzel, Vorlegung gemacht von bruder Johan tetzel prediger ordens ketzermeister: wyder eynen vormessen sermon von tzwentzig irrigen artickeln Bebstlichen Ablas und gnade belangende allen cristglaubigen menschen tzuwissen von notten (Leipzig: Melchior I Lotter, 1518), USTC 704278; and Martin Luther and Silvestro Mazzolini, In praesumptuosas Martini Luther conclusiones de potestate pape dialogus (Leipzig: Melchior I Lotter, 1518), USTC 689669, 689670.

${ }^{17}$ Steven Ozment, The Serpent and the Lamb: Cranach, Luther and the Making of the Reformation (New Haven, Conn.: Yale University Press, 2011); Max J. Friedlander and Jakob Rosenberg, Lucas Cranach (New York: Tabard, 1978); Dieter Koepplin and Tilman Falk, Lukas Cranach, 2 vols. (Basel: Birkhäuser, 1974); and Claus Grimm, Johannes Erichsen, and Evamaria Brockhoff, eds., Lucas Cranach: Ein Maler-Unternehmer aus Franken (Regensburg: Pustet, 1994).
} 
own press, and with characteristic thoroughness he also obtained his own paper mill - that way he would have control of the whole production process.

Cranach ran his own printing press for only a few years. ${ }^{18}$ But even after he had sold this on, he remained intimately involved in the local printing industry, since his workshop enjoyed an effective monopoly on the production of illustrative and decorative woodcuts. It was this that allowed Cranach to transform the look of Wittenberg books. ${ }^{19}$ To this point, Wittenberg imprints had mostly been associated with the spare utilitarian texts of RhauGrunenberg. Printers outside Wittenberg had improved the look somewhat, using decorative borders to frame the title. Cranach offered a radically new solution: a title page frame, made up not of separate panels, but a single woodcut. Here the design was allowed to flow around a blank central panel into which the text of the title could then be inserted. It was a masterpiece of design innovation, with one step solving a complex problem of integrating text and decorative material while allowing space for imaginative artistic expression on the front of the book. The block borders of the early Luther editions published in Leipzig and elsewhere tend to be dark and densely patterned. The Wittenberg frames have a lightness of touch, a clarity of line, so they serve to place the work, but not to draw the eye away from the central elements: the title, the name, the place.

Cranach brought to this new engagement with book design the accumulated experience of one of Germany's most capable and imaginative artistic entrepreneurs. The result is a whole series of masterpieces in miniature, bringing to the title pages of Wittenberg's Reformation Flugschriften a balance, poise, and sophistication that they had to this point entirely lacked. The distinctive look provided by Cranach's title-page designs was the final component of a puzzle that had been taxing Germany's printers since the early days of the Reformation: how to make the most of their most marketable property, the new phenomenon that was Martin Luther. Now every element was in place: a title-page border that arrested the eye, and a text that highlighted the two most significant elements of what was on offer: Luther's name and the place of origin-Wittenberg.

This was brand Luther. Piled up on the booksellers' stalls, these books would be instantly recognizable as the works of Luther and his Wittenberg coterie, and these were precisely the sort of books that both booksellers and their customers were keenest to get hold of. Another testimony to Cranach's design success can

\footnotetext{
${ }^{18}$ John L. Flood, "Lucas Cranach as Publisher," German Life and Letters 48, no. 3 (July 1995): 241-263.

${ }^{19}$ Andrew Pettegree, Brand Luther: 1517, Printing and the Making of the Reformation (New York: Penguin, 2015); and Tilman Falk, "Cranach-Buchgraphik der Reformationszeit," in Lukas Cranach, Koepplin and Falk, 1:307-412. See also Cranach im Detail: Buchschmuck Lucas Cranachs des Älteres und seiner Werkstatt (Wittenberg: Lutherhalle, 1994).
} 
be seen in the speed with which Cranach's work was copied elsewhere. Drew Thomas, who is currently investigating Cranach counterfeits, has found quite an amazing number. ${ }^{20}$ In a world of weak copyright, printing was an industry that evolved through imitation. Publishers went to the Frankfurt Fair as much to look as to buy. The plunder of his artistic genius was the greatest compliment to Cranach's work, and it too helped spread the Reformation.

By this point, Luther and Wittenberg had achieved a transformation in the German print world. The tiny local industry of Wittenberg had been transformed, as it would be again in the course of the $1520 \mathrm{~s}$, with the arrival of four more men who would establish their own long-lived publishing firms: Hans Lufft, Georg Rhau, Schirlentz, and Klug. By the time of Luther's death in 1546, his city had been reborn: no longer the down-at-heel town of wooden houses and mean streets to which he had reluctantly turned his steps in 1511 but a new city of stone-built mansions, some of them owned by the princes of the publishing trade. Luther was not only Wittenberg's leading intellectual force and icon; he was also the motor of the city economy.

\section{Degrees of AnONymity}

As Luther lay dying in 1546, he could at least take comfort that his German church would live on; even the Emperor's crushing military victory in the Schmalkaldic War (1547) could not force the restoration of Catholic worship in places that had instituted an evangelical polity. Outside Germany, the perspectives were far less rosy. For our second act we turn our attention to the beleaguered evangelical movements in the powerful states of western Europe, where the initial interest in Luther's message had failed to coalesce as a cohesive church. This was partly because Luther himself was too parochial a figure to provide the same model of leadership to churches outside his native land. In his later years, Luther scarcely moved out of Saxony, and his intellectual energies were almost entirely focused on German problems and German parishioners. After the trauma of the Peasants' War, Luther also found it impossible to conceive a church established without the support of the state power. When, in 1530, a delegation of evangelicals traveled from Antwerp to ask Luther's blessing on their efforts to establish a church, he offered no encouragement: they should conform to the established order or leave the Low Countries. The initial promise of evangelical reform in the Low Countries, fueled by considerable

\footnotetext{
${ }^{20}$ Drew Thomas, "Cashing in on Counterfeits: Fraud in the Reformation Print Industry," in Buying \& Selling: The Business of Books in Early Modern Europe, ed. Shanti Graheli (Leiden: Brill, 2017).
} 
public interest, was quickly dissipated, crushed between the determination of Charles $\mathrm{V}$ to permit no Lutheran preaching in his patrimonial lands and Luther's own indifference. In France, after initial flirtation with the rhetoric of reform, Francis I would adopt the same uncompromising line, and Luther's bad-tempered quarrel with Henry VIII ensured that the English king would have no truck with Wittenberg. ${ }^{21}$

In all of these places, legislation was enacted to prevent the production, circulation, or even authorship of Lutheran texts. This set printers sympathetic to the Reformation a quite different set of problems. The confident branding that immediately identified Luther's works to potential purchasers in Wittenberg or Augsburg was impossible. Indeed, the discovery of any text that could be connected to Luther put both printer and purchaser in deadly peril.

In these very different circumstances, Reformation print could not be confidently proclaimed; rather, it had to be smuggled into the hand of sympathizers without placing them in evident danger. Any of Luther's texts now published in French, Dutch, or English were carefully disguised as orthodox devotional texts of the sort popular and abundant in the early sixteenth-century print world. ${ }^{22}$ As a further precaution, printers often withheld their names from the title page and used only commonplace typefaces, without any of the decorative features that would normally advertise their workmanship. That way, even if books fell into the wrong hands, they would not give away the printer's identity. By and large this worked well enough; indeed, so well, that it is only in relatively recent times that some of these texts have been recognized as the work of Luther. ${ }^{23}$ Even so, the dangers and stresses of life in underground communities of evangelical sympathizers did take their toll. By the time of Luther's death, those who followed the teachings of the German reformers had been mostly forced either to take refuge abroad or to revert to conformity. The burden of persecution fell increasingly on more radical figures, such as the Dutch Anabaptists, who had repudiated Luther as emphatically as the Catholic Church.

The middle decades of the century brought an evangelical revival, but one, significantly, that looked not to Wittenberg for inspiration but to the Swiss

\footnotetext{
${ }^{21}$ On the Netherlands, see especially Alastair Duke, Reformation and Revolt in the Low Countries (London: Hambledon, 1990); and Richard Rex, "The English Campaign Against Luther in the 1520s," Transactions of the Royal Historical Society, 5th ser., 39 (1989): 85-106.

${ }^{22}$ Casper Christiaan Gerrit Visser, Luther's Geschriften in de Nederlanden tot 1546 (Assen: Van Gorcum, 1969); and Francis Higman, Piety and the People: Religious Printing in French, 15111551 (Aldershot: Ashgate, 1996).

${ }^{23}$ Francis Higman, "Les traductions françaises de Luther," in Lire et découvrir: La circulation des idées au temps de la Réforme (Geneva: Droz, 1998), 201-232.
} 
Reformed Churches. French evangelicals had their own reformer in John Calvin, a religious refugee now firmly established in a new mother church in Geneva. The Dutch had their own places of refuge in England and Germany, principally in London and Emden. Despite continuing persecution, congregations of Protestant believers began to meet for worship, and were not discouraged from doing so by the exile leadership. These underground churches gradually grew in strength, as efforts to root them out manifestly failed. Once again, print played its part. ${ }^{24}$ From Geneva, traveling salesmen carried baskets of books across the mountains into France, where they were distributed through the Protestant underground. ${ }^{25}$ For the Dutch, Emden became the new center of evangelical printing. ${ }^{26}$ As the movement grew in confidence, so did the typography. Works by Calvin and other leading reformers were not explicitly identified as such; but the disposition of type and choice of typefaces were sufficiently distinctive as to be clearly recognizable to those who sought them out.

Some years ago, I traveled to Hanover to see a single volume, which I believed to be a work by the Emden printer Gilles van der Erve (Ctematius). When the book arrived, it took less than five seconds to confirm this as his handwork, since by now I knew his style and the fonts of type at his disposal extremely well. ${ }^{27}$ As I was on my way back to the airport, it struck me that if this was so obvious to me, it must have been equally obvious to any alert ecclesiastical officer charged with rooting out heresy who had seen other examples of van der Erve's work. The same thought occurred when I examined a group of Calvinist texts published in Normandy, at Caen, in the first years of the French Wars of Religion and the years immediately preceding. $^{28}$ These were quite obviously the work of a small group of printers who had taken advantage of the rapid growth of Huguenot congregations, and indeed were themselves committed members of the churches. They exploited the gradual loosening of controls to reprint Genevan staples of congregational worship for the local churches.

It struck me that what we have here is rather different from the heavily disguised editions of Luther. Rather, they are seeking a middle way between

\footnotetext{
${ }^{24}$ Jean-François Gilmont and Rodolphe Peter, Bibliotheca Calviniana: Les oeuvres de Jean Calvin publiés au XVIe siècle, 3 vols. (Geneva: Droz, 1991-2000); and Gilmont, John Calvin and the Printed Book, trans. Karin Maag (Kirksville, Mo.: Truman State University Press, 2005).

${ }^{25}$ H. L. Schlaepfer, "Laurent de Normandie," in Aspects de la propagande religieuse, ed. G. Berthoud (Geneva: Droz, 1957), 176-230.

${ }^{26}$ Andrew Pettegree, Emden and the Dutch Revolt: Exile and the Development of Reformed Protestantism (Oxford: Clarendon, 1992).

${ }^{27}$ Den Christlichen Gemene, so ym Dhome tho Bremen Predige hören Getüchenisse (Emden: Gellius Ctematius, 1560); and Pettegree, Emden and the Dutch Revolt, no. 110.

${ }^{28}$ Andrew Pettegree, "Protestantism, Publication and the French Wars of Religion: The Case of Caen," in The French Book and the European Book World (Leiden: Brill, 2007), 43-63.
} 
the brazen self-advertisement of the Cranach Wittenberg editions and true concealment. By 1561, it was becoming increasing obvious that efforts to persecute French Calvinism into oblivion had failed. ${ }^{29}$ Churches in places like Caen were meeting more or less openly and attracting numerous followers - all of them needed Testaments, psalm-books, and catechisms. On the other hand, it was not yet clear that attempts to obtain formal toleration would succeed; the balance of political and confessional forces remained volatile and unpredictable. The appearance of the Caen editions reflected this state of uncertainty. On the one hand, these editions would have been immediately recognizable to their intended purchasers; but because the printers did not explicitly identify them as their own work, the local authorities could look the other way. The absence of imprint gave them plausible deniability, and if Catholic control was ever reestablished (as indeed it shortly was), the city magistrates might hope to avoid awkward questions as to why they had not enforced the law more rigorously.

In other words, we see something more subtle than a binary choice between books published with full bibliographical details and truly anonymous works. There are gradations between, levels of anonymity, appropriate to times when the evangelical churches enjoyed some level of freedom, but the future was not yet clear. We see the same phenomenon in the Netherlands in 1566, when the Dutch Revolt enjoyed its first brief springtime of hope. By this time, the Emden presses had their own badge of identity, a printer's mark so recognizably evangelical that it was even pirated by printers back in the Low Countries, as they scrambled to exploit the brief surge of demand for evangelical literature in the summer of the so called "Year of Wonders.",30

\section{Dr. Bouma’s Sin of Pride}

In any event, neither the Calvinists of Normandy nor the Antwerp church would enjoy the freedoms they had so confidently anticipated during these heady times in the 1560s. Within a decade, French Calvinism was confined to a battered rump, fighting for survival in the south of France. In the Netherlands, it would not be in the heartlands of Flanders and Brabant, but in the northern province of Holland that the Calvinist churches finally

\footnotetext{
${ }^{29}$ Philip Benedict, Rouen during the Wars of Religion (Cambridge: Cambridge University Press, 1981).

${ }^{30}$ In the bibliography of Willem Heijting, De Catechismi en Confessies in de Nederlandse Reformatie tot 1585, 2 vols. (Nieuwkoop: De Graaf, 1889): Catechismus, ofte onderwijsinghe in de christelicke leere, ghelijck in die kercken ende scholen der cheur vorstelicken Paltz, ghedreven oft gheleert wordt (Delft: H. Schinckel, 1566); Catechismus, oft christelicke onderrichtinghe, ghelijck die in kercken ende scholen der Cheur vorstelicken Paltz, ghedreven oft gheleert wort (Emden: Gellius Ctematius, 1563).
} 
established freedom from Spanish rule. By the end of the sixteenth century, Spain was forced to recognize the impossibility of recovering the northern provinces, and the Dutch Republic began its rapid ascent to its improbable status as Europe's most dynamic economy.

I want in the final section of this paper to consider the role of print in embedding the Calvinist Reformed Church at the heart of this new nation. The returning Calvinist exiles had played a crucial role in Holland's defiant resistance in the worst years of the conflict, and they had their reward when the principal churches in the liberated provinces were turned over to their use. But the citizen rulers of the new state had no wish to exchange Spanish rule for a new Calvinist theocracy. The Reformed enjoyed a privileged role in the new state- their ministers were the only ones to receive state salaries, for instance - but they did not exercise the sort of control over the temper of life that Calvin and his colleagues had achieved in Geneva. ${ }^{31}$ They were at liberty, as they wished, to thunder against vice and depravity from their pulpits, but their recommendations as to how society might be improved by legislation against such depravity were not always heeded. Crucially, other faiths were not persecuted and, in due course and to different degrees, were even afforded a degree of de facto toleration.

How were the churches sustained in a peculiar environment where not all citizens were obliged to attend the church, and the majority of those who did chose not to become full members? Once again, print played a crucial, and to some extent underappreciated, role. I say underappreciated because, if we know anything of the book world of the Dutch Republic, we think of the atlases of Blaeu and the elegant duodecimo classics of the Elzevier, a series self-evidently modelled on the Aldus editions that had taken the educated world by storm a century and a half previously; it was not just Luther and Cranach who appreciated the benefits of brand identity. ${ }^{32}$

But if we look closer, we see that these works, though rightly praised for their elegance and technical magnificence, do not represent the center of gravity of Dutch printing. Nor do the furious pamphlet exchanges that erupted all too often in this curiously unsettled state, most notably in the existential crisis of

\footnotetext{
${ }^{31}$ A. Th. van Deursen, Bavianen en Slijkgeuzen: Kerk en Kerkvolk ten Tijde van Maurits en Oldenbarnevelt (Assen: Van Gorcum, 1974). See also van Deursen, Plain Lives in a Golden Age: Popular Culture, Religion and Society in Seventeenth-Century Holland, trans. Maarten Ultee (Cambridge: Cambridge University Press, 1991): 233-318.

${ }^{32}$ David W. Davies, The World of the Elzevier (Leiden: Nijhoff, 1954), S. L. Hartz, The Elseviers and Their contemporaries: An Illustrated Commentary (Amsterdam: Elsevier, 1955); B. P. M. Dongelmans, P. G. Hoftijzer, and O. S. Lankhorst, eds., Boekverkopers van Europa. Het 17deeeuwse Nederlandse uitgevershuis Elzevier (Zutphen: Walburg, 2000); Joan Blaeu, Atlas Maior of 1665, ed. Peter van der Krogt (Cologne: Taschen, 2010); Herman de la Fontaine Verwey, "Willem Jansz Blaeu as a Publisher of Books," Quaerendo 3 (1973): 141-146; and De la Fontaine Verwey, "Dr. Joan Blaeu and his sons," Quaerendo 11 (1981): 5-23.
} 
1618-1619, when the Remonstrant wing of the Reformed church was effectively expelled, and many of the church's most distinguished ministers were dismissed from their livings. What we see if we dig deeper into the publishing culture is a religious writing of a very different spirit: a literature of quiet devotion, cherished and deeply read.

For this we do have to look very hard indeed, because what survives in library collections today is, in this respect, a poor guide to what was originally published. When editions of these devotional tracts do survive, this is invariably in one single copy; a fairly sure sign that there are many others that have disappeared altogether. But if this is the case, how can these lost editions be recovered? How can one identify books read, used, loved, and then discarded - the lost books of the early modern print world?

To develop this final section of my discussion, I need to introduce some very new work which is presently being undertaken in St. Andrews precisely to recover books that no longer survive in library collections, and thus to achieve a more holistic sense of what was originally published (and read). This sort of work is not uncontroversial in bibliographical circles, since material bibliography, quite correctly, has always cleaved close to the principles of cataloguing: that the best record will always be one made book in hand. But many books were lost in the great churning of libraries in the mid-twentieth century, often after the collections in question had been fully catalogued. Should we ignore these records simply because the books are now lost? And if these are to be incorporated, why ignore the mass of documentary material generated contemporaneously by those who published, bought, sold, and owned books; or even by those who sought to ban them. ${ }^{33}$

As it happens, the Dutch Republic generated a mass of records, both printed and archival, pertinent to a search of this nature. The Dutch were famous less for technological innovation than for the refinement of business practice, and this applied particularly to the book industry. The Dutch were the first to adopt the book auction, their newspapers were the first to carry advertisements, and their publishers issued a large number of stock catalogues, some with printed prices. ${ }^{34}$ All of these three sources generate a mass of new data about books offered for sale, and we can compare these records, often of high bibliographical quality, with the records of known surviving editions. The results are very illuminating.

\footnotetext{
${ }^{33}$ Flavia Bruni and Andrew Pettegree, eds., Lost Books: Reconstructing the Print World of PreIndustrial Europe (Leiden: Brill, 2016).

${ }^{34}$ Arthur der Weduwen, Dutch and Flemish Newspapers of the Seventeenth Century (Leiden: Brill, 2017). For auction catalogues, see especially, "Book Sales Catalogue Online: Book Auctioning in the Dutch Republic, 1599-ca. 1800," Brill, accessed 28 October 2017, http:// www.brill.com/products/online-resources/book-sales-catalogues-online.
} 
Let me, for instance, share with you a single advertisement placed in one of the Amsterdam weekly papers in $1643 .{ }^{35}$ In the early decades of the seventeenth century, most advertisements in these papers were for newly published books and mostly for one or two new titles. But this advertisement listed eight, all new editions of popular texts by the Amsterdam preacher and prolific author Roelof Pietersz:

D. Roelof Pietersz, Het Lof Jesu Christi onses Heeren, already published in 1643; Item, Het Lof der kercke Jesu Christi, already published in 1643; Item, 't Lof des Woordts Godts, ofte der H. Schrifture, published in 1640; Item, Scherm ende Schilt der kinderen Godes, an explanation of psalm 91; Item, De Spiegel der Barmhertigheyt en Gerechtigheyt Gods, in het vergeven en straffen der sonden; Item, De Enge poorte, ofte de Wegh der Saligheyt; Item, Eenige korte gulden Regelen eenes heyligen levens; Item, Den Evangelischen Arendt (all enlarged and reviewed, and improved according to the new translation of the Bible) (all Amsterdam, Marten Jansz Brandt). ${ }^{36}$

Brandt knew his market. He had taken eight of his most successful publications and revised them to conform to the new Statenbijbel. Brandt had published the Scherm ende Schilt der kinderen Godes already in 1631 and 1636, and would do so again in $1644 .{ }^{37}$ De Spiegel der Barmhertigheyt en Gerechtigheyt Gods, in het vergeven en straffen der sonden was published in 1628, 1632, 1640, and 1644 , in addition to this edition. ${ }^{38}$ For Eenige korte gulden Regelen eenes heyligen levens there are editions recorded for 1632, 1634, 1638, and 1641, all by Brandt. ${ }^{39}$ Den Evangelischen Arendt he published in 1637, 1639, and $1645 .^{40}$ Interestingly, none of the eight editions advertised here in 1643 can be linked to a surviving edition.

\footnotetext{
${ }^{35}$ Courante uyt Italien, Duytslandt, \&c., no. 39, 26 September 1643. See also Arthur der Weduwen and Andrew Pettegree, News, Business and the Birth of Modern Advertising: Advertisements and Public Announcements in Dutch and Flemish Newspapers, 1620-1675 (Leiden: Brill, 2019, forthcoming).

${ }^{36}$ This is a paraphrase of the original Dutch.

${ }^{37}$ Roelof Pietersz, Scherm en schilt der kinderen Godes (Amsterdam: Paulus Aertsz van Ravesteyn for Marten Jansz Brandt, 1631), USTC 1013422, (Brandt, 1636) USTC 1013433, (Brandt, 1644) USTC 1013421.

${ }^{38}$ The advertised edition is lost: Roelof Pietersz, De Spiegel der Barmhertigheyt en Gerechtigheyt Gods, in het vergeven en straffen der sonden (Amsterdam: Marten Jansz Brandt, 1643), USTC 1515575. For the other editions, see (1628) USTC 1030778, (1632) USTC 1020976, (1640) USTC 1013633, and (1644) USTC 1013875.

${ }^{39}$ Roelof Pietersz, Korte gulden Regelen eenes heyligen levens (Amsterdam: Marten Jansz Brandt, 1643), USTC 1515577, (Brandt, 1632) USTC 1013325, (Brandt, 1634) USTC 1013324, (Brandt, 1638) USTC 1016678, and (Brandt, 1641) USTC 1021123.

${ }^{40}$ Roelof Pietersz, Den evangelischen arendt (Amsterdam: Marten Jansz Brandt, 1643), USTC 1515578, (1637) USTC 1013433, (1639) USTC 1013622, (1645) USTC 1030787. A second part was published in 1645 (USTC 1013880) and a third part in 1650 (USTC 1014870).
} 
This, indeed, may only be the tip of the iceberg. We can see that Roelof Pietersz's Het Lof Jesu Christi onses Heeren is described as the second edition published in this same year, 1643. In the case of the De Enge poorte, ofte de Wegh der Saligheyt, Brandt would republish this again in 1646, where it is described as the seventh edition. ${ }^{41}$ None of the previous editions have yet been traced. ${ }^{42}$ This sort of phenomenon is not at all unusual. In 1642, Brandt published Het Lof des Heeren, described in the advertisement in the Tijdinghen uyt verscheyde Quartieren as the ninth edition. ${ }^{43}$ This edition does survive, but we can document only one other of the previous eight. Two years later, he offered an edition of Charles Drelincourt's Gebeden en Meditatien om sich te bereyden tot het $H$. Avondtmael. ${ }^{44}$ Drelincourt (1595-1669) was a popular French preacher, and this was the sixth edition of a translation by the Beverwijk preacher Gilles van Breen. This edition does not survive, and the only ones that do are an edition of 1639 and a further subsequent edition of $1649 .^{45}$

Here, then, is a mass of popular devotional literature, published and republished up to three times a year, and extremely poorly represented in surviving copies. Where editions do survive, this is very often in a single edition in one particular library, the library of the Free University in Amsterdam. Modern collectors would scarcely register if one of these books were to come on the market, because these texts, though neat enough, have none of the obvious attributes of collectability; they also generally do not command a sufficient price to register in seventeenth-century auction catalogues. But contemporary publishers and booksellers realized their value, for the Dutch Republic was, in the trade in books as with many other commodities, an economy that flourished through the realization of a large volume of business with small margins. And with these small devotional texts, the Dutch publishing world reached down into the realm of careful householders for whom the purchase of a book was a considered expense carefully weighed against other small domestic luxuries, and perhaps not in

\footnotetext{
${ }^{41}$ Roelof Pietersz, Enge poorte, ofte De wegh der saligheydt (Amsterdam: Marten Jansz Brandt, 1646), USTC 1013943.

${ }^{42}$ Though the same title is used for an earlier work by Eduard Poppius (1576-1624). See De enge poorte, ofte, Predicatien over eenighe voortreffelijcke texten der heyligher Schrifture (Gouda: Jasper Tournay for A. Burier, 1616), USTC 1010725, 1010728.

${ }^{43}$ Jacobus Trigland, Het lof des heeren (Amsterdam: Marten Jansz Brandt, 1642), USTC 1019080.

${ }^{44}$ Tijdinghen uyt verscheyde Quartieren, no. 9, 27 February 1644. See also Der Weduwen and Pettegree, News, Business and the Birth of Modern Advertising.

${ }^{45}$ Charles Drelincourt, Gebeden ende meditatien om sich te bereyden tot het H. avontmael, ende met yver daer toe te gaen.Vierde druck (Amsterdam: Marten Jansz Brandt, 1639), USTC 1021196, (1649) USTC 1019894.
} 
this case, with Roelof Pietersz's inspiring promise of salvation in the hereafter, even such a luxury.

I want to end this section by introducing one of my favorite characters from this busy world of devotional publishing, Dr. Gellius Bouma (1579-1658). Bouma was not one of the titans of the existential conflict that pitched the Contra-Remonstrant followers of Professor Gomarus against Professor Arminius and the Remonstrants. Bouma spent most of his career away from the epicenter of the conflict as a minister in Zutphen, on the border between Gelderland and Overijssel. Early in his working life, in common with so many Protestant ministers, he began work on a catechism. He sensibly suspended writing while he awaited the definitive resolution of the Remonstant controversy at the Synod of Dort, before resuming; the resulting work was published for the first time in 1621. A second edition was not required before 1625, but at this point Bouma began to develop more of a following; by the 1640s, the highpoint of the new state's economic growth and a hugely successful decade for the book industry, Bouma's catechism had become a runaway best seller and the leading catechism on the market.

Through all of this success, both personal and for the Dutch Republic, Bouma offered an inspiring vision of pious rectitude; but he was not, for all that, oblivious to the joys of authorial success. For the edition of 1647, the author composed a new preface, sketching the history of its composition and relating how, as publishers became aware of its popularity, he was inundated with requests from booksellers asking him to update his work to take into account the new official translation of the Bible - the same Statenbijbel that had created new opportunities for Marten Jansz Brandt and Roloef Pietersz. ${ }^{46}$ Yet if we rely only on the editions listed in the Dutch bibliography of early print, the Short-Title Catalogue Netherlands (STCN), this air of self-congratulation seems somewhat misplaced: the STCN lists six editions published before this edition of 1647 , a respectable total, but hardly overwhelming. ${ }^{47}$

But here we do Dr. Bouma an injustice; for when we begin to chase down references in other sources, the picture changes dramatically. It just so happens that, in precisely this period, the documentary literature available is particularly abundant. The Amsterdam newspapers survive in a decent run, Bouma's text is large enough to merit listing in auction catalogues as a

\footnotetext{
${ }^{46}$ Gellius Bouma, Christelicke catechismus der Nederlantsche gereformeerde kercken (Amsterdam: Theunis Jacobsz Lootsman, 1647), USTC 1013935.

${ }^{47}$ Gellius Bouma, Catechismus, welcke in den gereformeerden evangelischen kercken ende scholen der keur-vorstelijcken Pfaltz ende deser Nederlanden, geleert ende gheoeffent wordt (Amsterdam: Jan Fredericksz Stam for Hans Walschaert, 1628), USTC 1020106, (1631) USTC 1515005, (1635) USTC 1025135, (1642) USTC 1021181, (1644) USTC 1021008, (1646) USTC 1020107.
} 
separate lot, and the stock catalogue of Hendrick Laurensz, published on his death in 1649 , the height of the Bouma vogue, lists seven editions. ${ }^{48}$ We can also call upon the issues of Broer Jansz's Catalogus Universalis, an attempt to rival the famous Frankfurt Fair catalogue by listing all recent books published in the Dutch Republic, which was published once or twice a year for thirteen years between 1638 and $1651 .^{49}$

By the time we have incorporated all of this data, we have twenty-six editions published before 1651, and confirmed the work's status as a national bestseller. Two references confirm Bouma's recollection of first publication in 1621, an edition which has yet to be located in a surviving copy. In the following decades, it will go on to be published in ten different cities, in four different provinces, and in multiple formats.

Why does all this matter? It matters because the sort of books that were most intensively used by contemporaries were often the books that survive least well. A book like Bouma's catechism was used every day — that was the point- and constantly thumbed. It might never have found a safe haven on the shelves of a library, and might have been too tatty to be passed down the generations (by the time the parent died, children would most likely have had their own copy anyway). The books that survive best are those that do find their way into a library, often very quickly after publication, and they have survived the centuries in between often because they were not in fact much read.

Devotional texts, psalters, bibles, and catechisms were particularly vulnerable because they were usually too large to be bound together in collections (which is why so many pamphlets, rather counterintuitively, have survived well). Recovering the devotional world of these ordinary men and women in the pew requires rather more than simply relying on collective bibliographies of library stock - a search which will always privilege big, expensive books which libraries cherish over the small books that contemporaries read.

\section{The Challenge of Technological Change}

With this, we are reaching the end of our drama in three acts. We have witnessed a triumph of adaptation, and ingenuity, where the evangelical energies of a new religious movement were shaped and channeled by shrewd businessmen, who crafted a product suitable for hugely varying

\footnotetext{
${ }^{48}$ Catalogus variorum \& insignium librorum Hendrici Laurentii P.M. bibliopola Amsterodamensis. Quorum venditio habebitur Amsterodami, in cedibus defuncti die 20 julii 1649 (Amsterdam: For the Heirs of Hendrick Laurensz, 1649), USTC 1022549.

${ }^{49} \mathrm{~A}$ facsimile edition is available: H. W. de Kooker, ed. The Catalogus Universalis (Utrecht: $\mathrm{H} \& \mathrm{~S}, 1986)$.
} 
circumstances. The resulting reconfiguration of the print industry was very different from the elegant philological texts envisaged by the first boosters of print in the 1470 s.

This, of course, should not surprise us. Having lived through the latest wholesale media transformation, we know that new technology is always accompanied by a blizzard of false prophecy. The birth of the internet was initially perceived, in an eerie echo of humanist praise of print, as an ennobling tool of enlightenment, liberating and empowering public debate. The crystal ball of these technological optimists did not show them the rise of online betting or internet pornography; if they welcomed the prospect of citizen journalism, they would not have celebrated the internet troll; nor would they have anticipated the very recent epidemic of fake news. Seen as a means of empowerment, the digital revolution has instead ended up shaking the fundamental values that have for centuries underpinned the information economy, the need for intelligence to be verifiably true.

The fundamental problem that bedevils all transformative technological shifts is the difficulty of monetizing good intentions. In fifteenth-century Europe, Gutenberg's new technology was greeted through Europe with a sort of awed fascination. Every prince and every city yearned to have a part of this ingenious means of multiplying knowledge. But when the first excitement receded, it was left to the practical men of business, faced with huge debts in their ledgers and stacks of unsold copies, to bring fiscal discipline to the new industry. The Reformation offered the vital way forward: new products for new readers at affordable prices. Print played a vital role in spreading the evangelical message and embedding the new teachings. But the Reformation also did a great deal to usher print toward a sustainable future. 